\title{
Role of Manufacturing Industries in Nepalese Economy
}

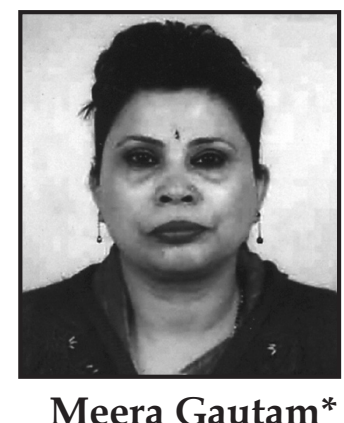

\begin{abstract}
Nepal is an agriculture country major labor force is employed, and contributes nearly thirty percent of GDP. Countries have adopted the policy of industrialization and create jobs for the economic active population. This paper discusses and tries to identify the role played by the manufacturing enterprises. Basically share in GDP, employment, value addition and gender participation. A simple average, straight line growth trend and percentiles are used for the role measurement. The source of data is mainly censuses on manufacturing enterprises conducted in Nepal since first one from1991 to last one in 2012 and Economic Survey. Analysis of the data indicates that the total number of operating establishments is declining, in the same way the total number of employees is also declining. The highest percentages of female workers are engaged as operative workers in all the CMEs. It is realized that whatever the status measured may help to the policy makers or researchers to correlate and analyze further. It is recommended the need of further information is needed on market opportunities and challenges in the past and present, investment and export potential and bottlenecks. This would be useful to entrepreneurs and policy makers alike.
\end{abstract}

Keywords- Census, Employment, Gender, Manufacturing Industry, Manufacturing Value Added,

\section{Introduction}

Nepal is an agriculture country where nearly 66.67\% (CBS 2015) of labor force are employed, and contributes 27.6\% in GDP (MoF 2018). 2008 Nepal labor force survey indicates that manufacturing sector employed nearly 6.6\% (NLFS 2008). In agriculture sector the over employed population needs to be diversified in other sector as well as population as of with their capacity needs to be employed. In this regard expansion of the manufacturing sector, both in terms of size and productivity can improve the status of population below poverty line through generating gainful employment and acceleration of country's economic prosperity.

Due to traditional method of farming, availability of quality and timely inputs, small farm size 0.66 ha with 3.2 numbers priority sector are considered as the factors for lower agriculture sector grow th as expected and desired by the policy and farmers. In this scenario manufacturing sector generally offers better opportunities in comparison to agriculture in such a way:

* Lecturer, Shanker Dev Campus, Tribhuvan University, Nepal 
$\checkmark$ Technological progress,

$\checkmark$ Transfer of surplus resources, if any, from agriculture to manufacturing,

$\checkmark$ Output growth, productivity and capital accumulation

$\checkmark$ Economies of scale, and

$\checkmark$ Positive spillover effects

In such situation it is needed to capitalize these opportunities with appropriate policies and strategies. The status of available information is tried to analyze the role status of policies and programs implemented by the government.

In each five years interval since 1964/65 fiscal year Central Bureau of Statistics (CBS) is conducting census of Manufacturing Establishment (CMEs) and in 2011/12 has completed $10^{\text {th }} \mathrm{CME}$. In each and every CME's covers the manufacturing establishments those who engage 10 or more economic active age persons within the Republic of Nepal's geographic boundary.

\section{Sector Issues and Problems}

Major obstacles to industrial development are Nepal's small domestic market, landlocked position, and limited skills and resource base. Industries catering to local markets face low disposable incomes and serious competition with Indian consumer goods industries, which benefit from economies of scale. In most hill areas, purchasing power, already below subsistence levels, increasing population density and the lack of unexploited arable land. In manufactured exports, Nepal's landlocked position results in high transport costs, a sizeable burden on export prices of low value items. Cottage industry production in the hills is constrained by seasonal demands from agriculture and limited commercial orientation of the artisans. Traditional techniques limit productivity. Most craftspeople are not entrepreneurs; their tradition, scale, and knowledge limit growth beyond the household level and necessitate services by market agents for distribution of inputs and finished products.

Till the date CBS publishes only statistical synopsis or abstract of each CME's. Even though there are covered different a number of indicators which can help to assess the performance of manufacturing establishments, besides the number of establishments, employment, wages and salaries, fixed assets, input, output and value added. The use of the information collected is mainly used for the estimating contribution of the sector in GDP.

But the information can be used for further analysis on various aspects mainly on the role evaluation of this sector. Thus, in this paper it is tried to evaluate its role in Nepalese economy or in employment, in GDP, Productivity, in Competitiveness and Conclusions and recommendations. 


\section{Data Analysis}

This paper is based on the secondary information published from governmental organization and limited to the availablelatest information like manufacturing establishment census (CME's) of 2011. The analysis of data in this paper is based on the latest Manufacturing establishment census 2011, official industrial statistics from the Ministry of industry 2015/2016 and latest economic survey from Ministry of Finance $(\mathrm{MoF})$. Here the analysis is based on the indicators available from the CME's and the MoF.

The data used are primarily those of the censuses of the manufacturing establishments conducted in 1996/97, 2001/02, 2006/07 and 2011/12 at the 2 digit level of the International Standard Industrial Classification Revision 3 (ISIC rev.3).

While calculating the growth rates the following Straight-Line formula is used.

$$
P R=\frac{\left(V_{\text {Present }}-V_{\text {past }}\right)}{V_{\text {Past }}} \times 100
$$

Where:

$\mathrm{PR}=$ Percent Rate

$\mathrm{V}_{\text {Present }}=$ Present or Future Value

$\mathrm{V}_{\text {Past }}=$ Past or Present Value

\section{Review of Manufacturing Sector Policy}

As mentioned and reviewed by SAWTEE -Nepal's manufacturing/ industrial policy can be roughly divided into two time-periods, pre-1985 and post-1985. Before 1985 policies were guided by inward looking protectionist strategies. Domestic industries were treated as 'infant industries' and were protected from foreign competition by high tariff and quota restrictions. The government was directly involved in the economy and provided essential products and services.

Liberalization initiated in 1985 and accelerated after the 1990s, sought to modernize the economy and accelerate structural changes by creating an environment appropriate for private sector participation. The government began to withdraw from the economy, and policies were implemented to promote private and foreign investment. A new liberal Industrial Policy was formulated in 1992. One of the major objectives of the Industrial Policy of 1992 is to privatize public sector industries. The policy seeks to create an open and competitive economy by curtailing government interference in price fixing of industrial goods. In addition, the policy aims to strengthen linkages between manufacturing and agriculture sectors and promote labor intensive, local resource based, export oriented industries. Private sector participation is also encouraged in community and private forest development, generation and distribution of hydro-electricity and in construction and management of nursing home, hospital, power propelled railway, roads, bridges, tunnels, ropeways etc. 
As reviewed by CBS 2014, despite these policy measures, the manufacturing sector did not improve as expected. The 1989-90 trade disputes with India are largely to blame: Nepal could not import many inputs and this caused lower capacity utilization in some industries and lost India as its traditional market for certain goods. Even in these trying times, the government of Nepal continued to provide support to the manufacturing sector. From 1992, all manufacturers exporting more than $90 \%$ of their products benefitted from the bonded warehouse system.

In 2010, a new Industrial Policy was introduced that replaced the 18-year old Industrial Policy 1992. It promises easy exit to the investors, recognizes subcontract manufacturing, promises tariff protection to local industries with high value addition, incorporates intellectual property protection provisions, and emphasizes employment creation and poverty reduction. Ensuring balanced industrial growth, backward linkages, protection and state-support to the industries are some of the key objectives of the policy.

Under the new Industrial Policy 2010, government support would be extended to the development of infrastructure to industries on a priority basis and special tax holidays were provided for industries in rural and unindustrialized areas. The new Policy 2010 is expected to accelerate manufacturing growth guided by timely rules, regulations and laws. It has many new provisions that would help create friendly relations between the government and private sector, and also help economic growth of the national economy by promoting the industrial sector in the country.

The policy aims to develop industrial infrastructure, such as roads, electricity and telecommunications in parts of the country having the potential for manufacturing and processing. The policy provides additional incentive packages to export industries, particularly the small and medium enterprises. It promises 25 per cent income tax concessions to small, medium and large industries that employ 100, 300 and 600 persons respectively.

The policy broadly categorized the geographical regions of the country into three groups extremely underdeveloped, underdeveloped and developing industrial regions and pledged holidays in income tax and excise duties for the industries in those regions for 12 years, 7 years and 5 years, respectively.

In addition to the existing Special Economic Zones (SEZs), the policy also envisages the development of Agro- Export Promotion Zones (AEPZs). The industries, established in both types of zones, are exempt from excise duty and value added tax on raw and packaging materials. It also recognizes research and development, and market promotion as integral parts of industrial activities, and allows $5 \%$ income tax deduction for each purpose.

The policy listed the following sectors under high priority: IT, cement, hydropower, vehicle \& motor parts, chemical fertilizer, bio-technology and adventure tourism. It also listed agriculture, forest-based industries, ayurvedic \& homeopathic medicine manufacturing, 
minerals and handicrafts as priority industries. The other provisions of the policy include no-work no-pay, business incubation center and industrial investment protection funds to compensate the ailing industries. Similarly, the policy envisages special package program to develop the Karnali industrial corridor and new industrial villages.

The year 2010 also saw the adoption of the Nepal Trade Integration Strategy, which identified 19 priority export sectors. In the manufacturing sector, these were instant noodles, handmade paper, silver jewellery, iron and steel, pashmina, and wool products. Dairy products were mentioned under additional potential export sector. Sector specific recommendations were derived from detailed Strength, Weakness, Opportunity, and Threat (SWOT) analyses.

\section{Role of Manufacturing Industries}

Here the role of manufacturing industries is discussed in details of the manufacturing sector in terms of its position in the economy, current structure.

\section{Manufacturing Industries- in GDP}

Nepal's manufacturing sector has not performed as the engine of growth. In fact, its share in GDP gradually declined from 9.0 per cent in 2000/01 to 5.39 per cent in 2017/18 (Table-1). Other sectors - transport, storage and communications and financial intermediation-increased their shares in the economy over the years. Still others showed minor changes. Agriculture maintained its dominant position with 27.10 per cent in 2017/18.

Table-1: Composition of gross domestic product by ISIC division at current price 2000/01 to $2012 / 13(\%)$

\begin{tabular}{|c|c|c|c|c|c|c|c|c|c|c|}
\hline NSIC & Industrial Classification & $2000 / 01$ & $2010 / 11$ & $2011 / 12$ & $2012 / 13$ & $2013 / 14$ & $2014 / 15$ & $2015 / 16$ & $\begin{array}{l}2016 / 17 \\
R\end{array}$ & 2017/18P \\
\hline A & Agriculture and forestry & 36.15 & 36.68 & 34.82 & 33.40 & 32.16 & 31.27 & 31.08 & 28.25 & 27.10 \\
\hline B & Fishing & 0.43 & 0.38 & 0.40 & 0.42 & 0.48 & 0.47 & 0.53 & 0.51 & 0.49 \\
\hline $\mathrm{C}$ & Mining and quarrying & 0.43 & 0.54 & 0.57 & 0.61 & 0.60 & 0.60 & 0.56 & 0.59 & 0.62 \\
\hline $\mathbf{D}$ & Manufacturing & 9.03 & 6.24 & 6.34 & 6.35 & 6.20 & 6.03 & 5.82 & 5.55 & 5.39 \\
\hline $\mathbf{E}$ & Electricity gas and water & 1.82 & 1.24 & 1.22 & 1.30 & 1.17 & 1.12 & 1.02 & 1.27 & 1.19 \\
\hline $\mathbf{F}$ & Construction & 6.01 & 6.93 & 6.86 & 6.93 & 6.93 & 7.06 & 6.80 & 7.27 & 7.60 \\
\hline $\mathrm{G}$ & Wholesale and retail trade & 16.44 & 13.90 & 13.79 & 14.54 & 14.90 & 14.69 & 14.11 & 13.43 & 13.26 \\
\hline $\mathbf{H}$ & Hotels and restaurants & 1.99 & 1.63 & 1.76 & 1.89 & 1.94 & 2.05 & 2.00 & 1.98 & 2.05 \\
\hline I & $\begin{array}{l}\text { Transport, storage and } \\
\text { communications }\end{array}$ & 7.39 & 8.20 & 8.51 & 8.90 & 8.55 & 8.37 & 8.06 & 7.40 & 7.97 \\
\hline J & Financial intermediation & 2.69 & 3.88 & 4.07 & 3.93 & 4.36 & 4.64 & 5.19 & 5.61 & 6.33 \\
\hline K & $\begin{array}{l}\text { Real estate, renting and } \\
\text { business activities }\end{array}$ & 8.29 & 8.23 & 8.57 & 8.81 & 8.40 & 8.47 & 9.21 & 11.09 & 11.37 \\
\hline $\mathbf{L}$ & $\begin{array}{l}\text { Public administration and } \\
\text { defence }\end{array}$ & 1.24 & 1.92 & 2.13 & 2.04 & 2.43 & 2.61 & 2.54 & 2.96 & 2.88 \\
\hline $\mathbf{M}$ & Education & 4.08 & 5.25 & 5.69 & 5.79 & 6.33 & 6.56 & 6.82 & 7.20 & 7.17 \\
\hline $\mathbf{N}$ & Health and social work & 0.98 & 1.32 & 1.42 & 1.41 & 1.52 & 1.67 & 1.62 & 1.75 & 1.68 \\
\hline $\mathbf{O}$ & $\begin{array}{l}\text { Other community, social and } \\
\text { personal service activities }\end{array}$ & 3.03 & 3.64 & 3.86 & 3.67 & 4.04 & 4.39 & 4.65 & 5.13 & 4.90 \\
\hline
\end{tabular}


Figure 1 gives the average growth rates of value added by sector from 2000/01 to 2017/18 (for more details on growth rates per year (Table 2). The average growth rate of manufacturing value added per capita is over 2000/01 -2017/18 periods: 2.02 per cent. The fastest growing sectors were: education (13.24\%), Health and social work (12.71\%), Financial intermediation (11.94\%) , Public administration and defense (11.84\%), Other community, social and personal service activities (10.82\%), Fishing (11.49\%) transport, storage and communication (9.61\%), and various services (together about 10.82\%).

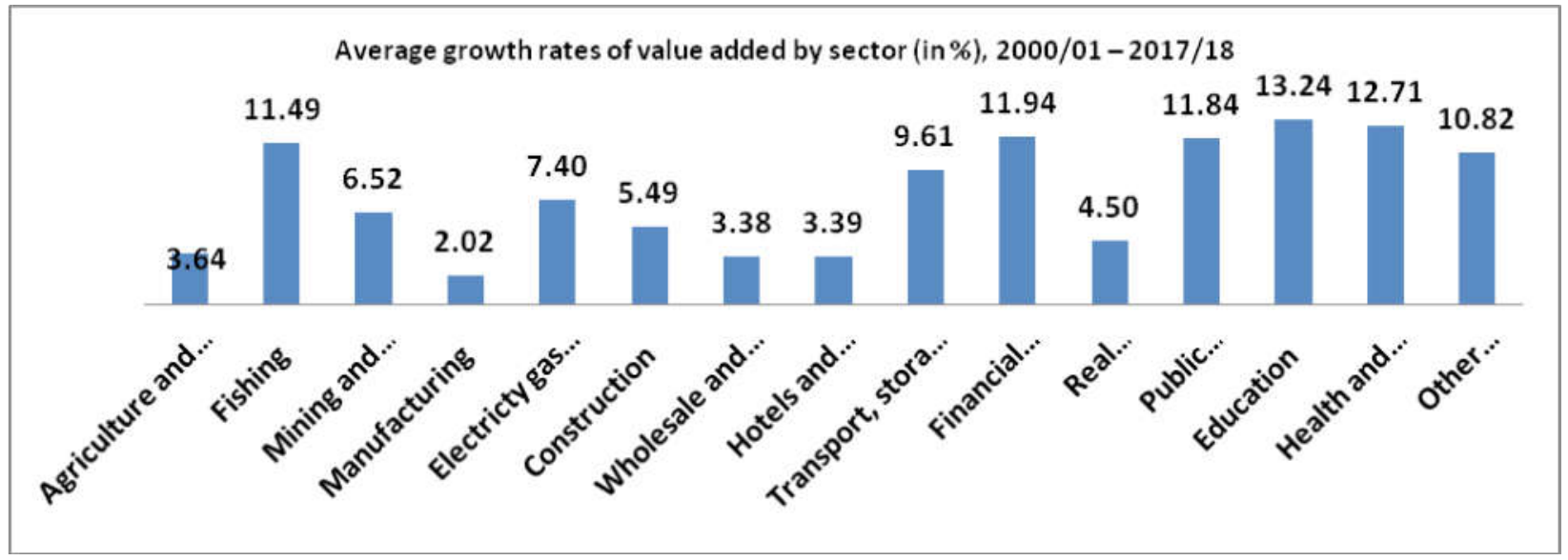

Manufacturing Industries- Structural Change

Although the share of manufacturing in total GDP decreased from 9.03 per cent to 5.39 per cent (Table -1), the manufacturing sector underwent some substantial changes in its composition by sub-sectors based on CME's (Figure 2). The major change is the increase of the share in value added of the food and beverages sector from 22.8 per cent in 1996 to 34.0 per cent in 2011. This went up at the expense of textiles (from 25.9 per cent to 3.8 per cent), and wearing apparel and fur (from 6.3 per cent to 0.5 percent).

All these sectors are classified as low technology sectors but within these the food sector can be regarded as the first step towards industrialization. It is driven by domestic demand and uses mainly agricultural inputs, with low value added to input ratios. Thus, apart from a declining contribution to the total GDP, the manufacturing sector also retreated towards more basic industries.

From a policy perspective, this means that agro-based industries should be taken as one of the starting points for quality improvements, product diversification, technological development, competition with imports, and export expansion.

Similar to its share in a number of manufacturing industries, food and beverages contributed the highest share in the value added, in both 2006 and 2011. In 1996, the value added from textiles was the highest among other branches. The share of value added from food and beverages in the last 15 years increased from 23 per cent in 1996 to 34 per cent in 2011. Similar patterns were observed for non-metallic mineral products (7 per cent in 1996 to 14 per cent in 2011). 
Value added from textiles significantly decreased over the years. It decreased by 6 percentage points from 2006 to 2011 and by 22 percentage points from 1996 to 2011. Although tobacco products based manufacturing has only around 1 percent share in the total number of manufacturing, its share in value added has been very significant (12 per cent in 1996, 17 per cent in 2006 and 13 per cent in 2011) standing 2nd and 3rd in total share in value added. This might be the case because the output was reported at market prices (including tax).

Table 2: Value added (in million Rs) and its share by 2 digit ISIC branches

\begin{tabular}{|c|c|c|c|c|c|c|c|}
\hline \multirow[b]{2}{*}{ ISIC } & \multirow[b]{2}{*}{ Description } & \multicolumn{2}{|c|}{ CME 1996} & \multicolumn{2}{|c|}{ CME 2006} & \multirow{2}{*}{$\frac{\mathrm{CME}}{\mathbf{V A}}$} & \multirow{2}{*}{$\begin{array}{l}2011 \\
\begin{array}{l}\% \\
\text { Share }\end{array}\end{array}$} \\
\hline & & VA & $\%$ Share & VA & $\%$ Share & & \\
\hline 15 & Food and beverages & 4996 & 22.8 & 12907 & 27.0 & 30865 & 34.0 \\
\hline 16 & Tobacco products & 2624 & 12.0 & 8164 & 17.1 & 11921 & 13.1 \\
\hline 17 & Textiles & 5673 & 25.9 & 4873 & 10.2 & 3425 & 3.8 \\
\hline 18 & Wearing apparel, fur & 1376 & 6.3 & 668 & 1.4 & 486 & 0.5 \\
\hline 19 & $\begin{array}{l}\text { Leather, leather products and } \\
\text { footwear }\end{array}$ & 288 & 1.3 & 293 & 0.6 & 771 & 0.8 \\
\hline 20 & Wood products (excluding furniture) & 309 & 1.4 & 615 & 1.3 & 1798 & 2.0 \\
\hline 21 & Paper and paper products & 370 & 1.7 & 2007 & 4.2 & 904 & 1.0 \\
\hline 22 & Printing and publishing & 316 & 1.4 & 541 & 1.1 & 571 & 0.6 \\
\hline 23 & $\begin{array}{l}\text { Coke, refined petroleum products, } \\
\text { nuclear fuel }\end{array}$ & 33 & 0.2 & 942 & 2.0 & 366 & 0.4 \\
\hline 24 & Chemicals and chemical products & 1318 & 6.0 & 3897 & 8.1 & 6976 & 7.7 \\
\hline 25 & Rubber and plastics products & 649 & 3.0 & 2004 & 4.2 & 4225 & 4.7 \\
\hline 26 & Non-metallic mineral products & 1584 & 7.2 & 3758 & 7.9 & 12716 & 14.0 \\
\hline 27 & Basic metals & 386 & 1.8 & 2418 & 5.1 & 4903 & 5.4 \\
\hline 28 & Fabricated metal products & 1095 & 5.0 & 3409 & 7.1 & 8117 & 8.9 \\
\hline 29 & Machinery and equipment n.e.c. & 18 & 0.1 & 132 & 0.3 & 270 & 0.3 \\
\hline 31 & Electrical machinery and apparatus & 483 & 2.2 & 547 & 1.1 & 772 & 0.8 \\
\hline 32 & $\begin{array}{l}\text { Radio, television and communication } \\
\text { equipment }\end{array}$ & 59 & 0.3 & 188 & 0.4 & 492 & 0.5 \\
\hline 34 & Motor vehicles, trailers, semi-trailers & 5 & 0.0 & 23 & 0.0 & 82 & 0.1 \\
\hline 36 & Furniture; manufacturing n.e.c. & 292 & 1.3 & 449 & 0.9 & 1169 & 1.3 \\
\hline Total & 21874 & & 100 & 47835 & 100 & 90829 & 100 \\
\hline
\end{tabular}




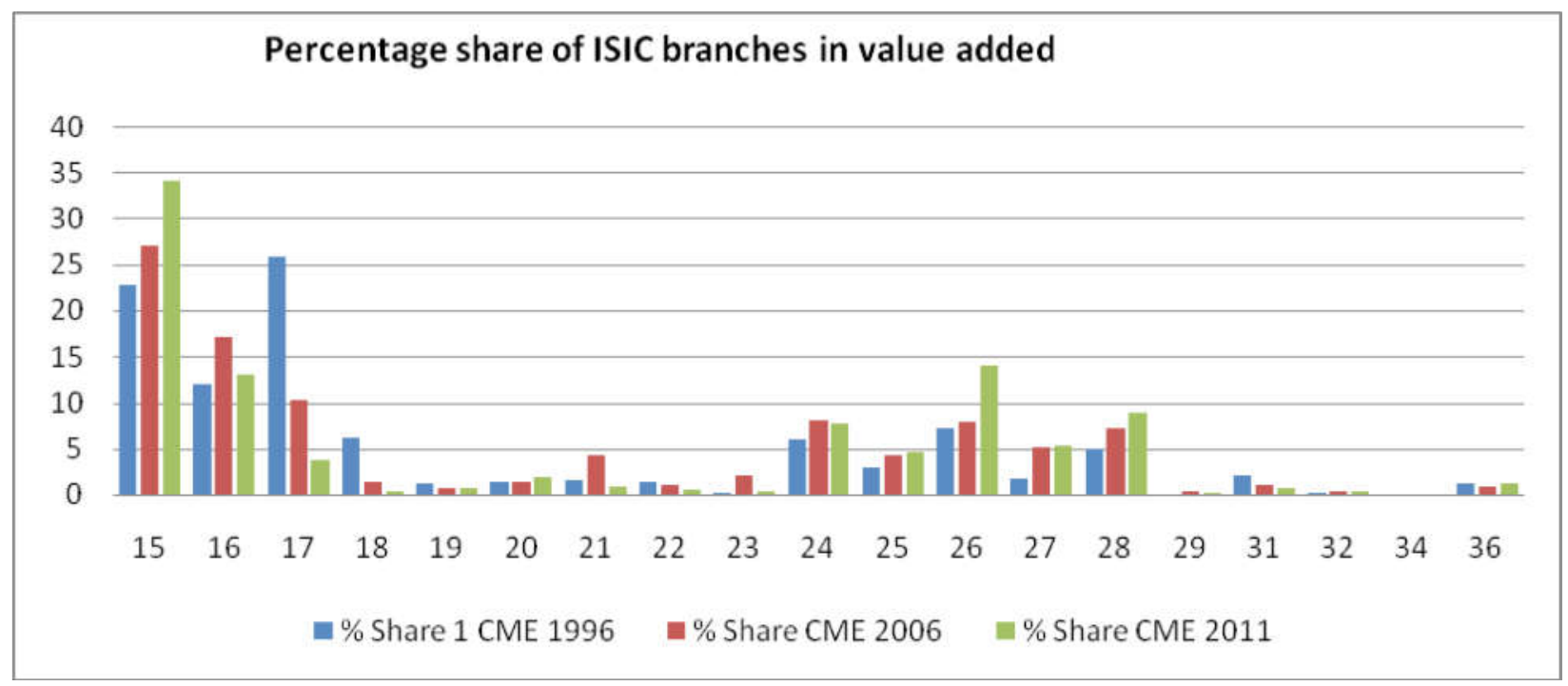

\section{Manufacturing Industries-Productivity}

Industrial performance of a nation is an outcome of various social, economic and technological factors. Productivity, structural change and competitiveness are considered main dimensions of industrial performance. Here an attempt is made to discuss various measures of productivity. Productivity is an important measure of the efficiency of production and its productivity performance indicator is a crucial variable for industrial policy making.

Productivity is a ratio of a measure of output to a measure of input use. In practice, it is derived from the ratio of the value of real output to the value of input over a period of time of the nation. But a precise measurement of productivity is not so straightforward, especially due to the complexity of input components. In economic statistics, inputs are disaggregated into two major groups. The first one is primary inputs (also known as factors of production) comprising labour input and capital input and the second one is intermediate inputs (materials and supplies, energy, industrial services, etc.). The change in productivity occurs as a result of the change in the efficiency of the use of all these inputs. An approximate estimation of the combined effect of a change in primary inputs on output is called total factor productivity.

Productivity can be measured in different ways, depending on the definition of output and input components or measures. The following partial productivity indicators are discussed below: value added per capita, value added per employee, value added per unit of capital, value added per output total factor productivity, while the share of training in wages and salaries is presented in Section 0 as an indication of the efforts by firms to improve productivity by labor skill improvements.

\section{Current and Past structure as of CME's}

The current status of the manufacturing industries is analyzed on the basis of the size of the manufacturing establishments, number of employees, wages/salaries, investments, inputs, output, and value added. In addition, tried to estimate the structure of the firms: the average 
number of employees per establishment, inputs as percentage of output, Manufacturing Value Added (MVA)/employee, MVA/output ratio, and MVA/capital ratio.

Table-3: Indicators' index of the manufacturing sector by census year

\begin{tabular}{|l|l|l|l|l|l|}
\hline \multirow{2}{*}{ Description } & \multicolumn{5}{|l}{ Principal Indicators' Index (1991/92=100) } \\
\cline { 2 - 6 } & $\mathbf{1 9 9 1 / 9 2}$ & $\mathbf{1 9 9 6 / 9 7}$ & $\mathbf{2 0 0 1 / 0 2}$ & $\mathbf{2 0 0 6 / 0 7}$ & $\mathbf{2 0 1 1 / 1 2}$ \\
\hline No. of establishments & 100 & 83 & 75 & 81 & 95 \\
\hline No. of employees & 100 & 88 & 85 & 80 & 91 \\
\hline $\begin{array}{l}\text { Wages/Salaries \& other benefits to } \\
\text { employees }\end{array}$ & 100 & 89 & 114 & 114 & 146 \\
\hline $\begin{array}{l}\text { Gross fixed assets at the end of the } \\
\text { year }\end{array}$ & 100 & 97 & 120 & 187 & 177 \\
\hline Input & 100 & 125 & 193 & 265 & 353 \\
\hline Output & 100 & 122 & 172 & 225 & 289 \\
\hline Value added & 100 & 118 & 143 & 168 & 198 \\
\hline Average no. of employees per firm & 100 & 105 & 113 & 99 & 96 \\
\hline Input as percentage of output & 100 & 103 & 112 & 118 & 122 \\
\hline MVA/Employee & 100 & 134 & 168 & 211 & 217 \\
\hline MVA/Output ratio & 100 & 96 & 83 & 75 & 68 \\
\hline MVA per unit of capital & 100 & 121 & 119 & 90 & 112 \\
\hline
\end{tabular}

Table 3 (Based on the annex-1) provides an interesting overview of what happened to the manufacturing sector in terms of the above indicators comparing various census years to the year 1991/92.

The total number of operating establishments declined by $17 \%, 25 \%, 19 \%$, and $5 \%$ in the year 1996/97, 2001/02, 2006/07 and 2011/12 respectively. The total number of employees declined by 12\%, 15\%, 20\% and 9\% in CME year 1996/97, 2001/02, 2006/07 and 2011/12 respectively (Fig-3). The average size of manufacturing establishments fluctuated over the years with a peak in 2001/02. Real wages/salaries (including other benefits) declined by $11 \%$ in 1996/97, increased by $14 \%$ in $2001 / 02$ and $2006 / 07$ and by $46 \%$ in $2011 / 12$, Gross fixed assets at the end of the year decreased by $3 \%$ in 1996/97 and increased by $20 \%, 87 \%$ and $77 \%$ in 2001/02, 2006/07 and 2011/12 respectively. Inputs rapidly increased by 25\%, 93\%, 165\% and $253 \%$ in the year 1996/97, 2001/02, 2006/07 and 2011/12 respectively. However, real output increased only by $22 \%, 72 \%, 125 \%$ and $189 \%$ in the year 1996/97, 2001/02, 2006/07 and $2011 / 12$ respectively. As a consequence, inputs per unit of output gradually increased by $3 \%, 12 \%, 18 \%$ and $22 \%$ over the four census years; Value added of manufacturing industries significantly increased by 18\%,43\%, 68\% and 98\% in the CME year 1996/97, 2001/02, 2006/07 and 2011/12 respectively. 
Besides these the MVA/Employee, the measure of labour productivity of the manufacturing industries increased by 34\%,68\%,111\% and 117\% in the year 1996/97, 2001/02, 2006/07 and 2011/12 respectively; MVA per unit of capital somewhat erratically behaved, particularly for the year 2006/ 07 (Fig-3); this could have been caused by changes in the utilization of capacity for the year. The MVA/Output ratio decreased by $4 \%, 17 \%, 25 \%$ and $32 \%$ in the CME year 1996/97, 2001/02, 2006/07 and 2011/12 compared to the CME year 1991/92, indicating that inputs are at a higher proportion of output, perhaps the result of a structural change towards agro-based industries (Fig- 4).
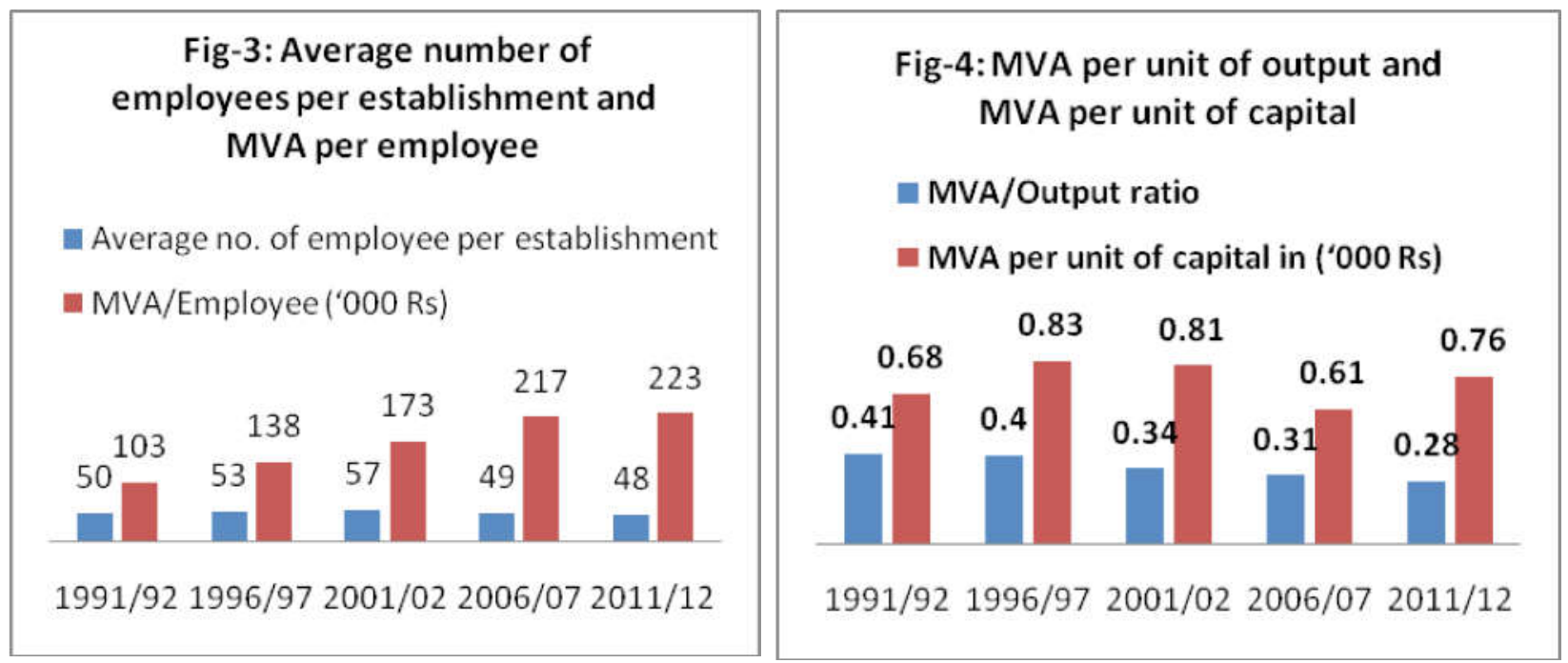

\section{Manufacturing Industries-Social inclusiveness,}

Following the review of the role of the manufacturing sector in the above sections, Here it is tried to analyse the impact of the manufacturing sector on gender. Since the manufacturing sector in Nepal is small and not dynamic, it cannot be expected to play a strong role in mitigating economy-wide imbalances. Imposing too many constraints on the sector may be counterproductive in the long run. Yet, good labour relations, gender equality and environmental health can be pursued simultaneously with modern developments in manufacturing.

The unequal distribution of the country's resources between individuals and groups in society in terms of region, caste/ethnicity and gender can give rise to social exclusion. It can be measured by various indicators. It may include multidimensional poverty, inequality, equity, social cohesion, and empowerment. Here, only the disparity in terms of gender in the formal manufacturing sector is highlighted.

\section{Gender Employment Status of the Manufacturing Sector}

The per cent of women workers as percentage of the total workforce is one of the indicators to measure social inclusion. In all of the four manufacturing and establishment census years, less than 20 per cent women are working. Table 4 shows that out of the total manufacturing employment, around 5 per cent women are working as administrative workers and less than 
5 per cent women as technical workers from 1996/97 to 2011/12. The highest percentages of female workers are engaged as operative workers in all the CMEs.

Table 4: Number of paid employees by sex and type of employment (1996/97-2011/12)

\begin{tabular}{|c|c|c|c|c|c|c|c|c|c|c|c|c|}
\hline \multirow[b]{2}{*}{$\begin{array}{l}\text { Census } \\
\text { Year }\end{array}$} & \multicolumn{3}{|c|}{ Administrative } & \multicolumn{3}{|c|}{ Technical } & \multicolumn{3}{|c|}{ Operative worker } & \multicolumn{3}{|l|}{ Total } \\
\hline & Male & Female & $\begin{array}{lll}\% & \text { o } & f \\
\text { Female }\end{array}$ & Male & Female & $\begin{array}{lll}\% & \text { o } & f \\
\text { Female }\end{array}$ & Male & Female & $\begin{array}{ccc}\% & \text { o } & f \\
\text { Female }\end{array}$ & Male & Female & $\begin{array}{lll}\% & \text { o } & f \\
\text { Female }\end{array}$ \\
\hline 1996/97 & 17668 & 915 & 4.9 & 5561 & 221 & 3.8 & 123668 & 39283 & 24.1 & 146897 & 40419 & 21.6 \\
\hline $2001 / 02$ & 20522 & 1166 & 5.4 & 10585 & 243 & 2.2 & 116902 & 32525 & 21.8 & 148009 & 33934 & 18.7 \\
\hline 2006/07 & 19268 & 1362 & 6.6 & 8381 & 364 & 4.2 & 112830 & 27686 & 19.7 & 140479 & 29412 & 17.3 \\
\hline 2011/12 & 19142 & 1089 & 5.4 & 9416 & 298 & 3.1 & 130618 & 34426 & 20.9 & 159176 & 35813 & \\
\hline
\end{tabular}

\section{Conclusions and Recommendations}

The information collected by various CMEs follows standard prescriptions of international conventions. To a large extent, the data collected provide a good general picture of the manufacturing sector over time and include many details relevant to specific users.

The analysis carried out has highly encouraged to the researcher to go further inside.

It is realized that whatever the status measured may help to the policy makers or researchers to correlate and analyze further. It is recommended the need of further information is needed on market opportunities and challenges in the past and present, investment and export potential and bottlenecks. This would be useful to entrepreneurs and policy makers alike.

\section{References}

CBS 2010. Nepal Labor Fource Survey 2008, National Planning Commission Secretariat, Central Bureau of Statistics, Kathmandu, Nepal

CBS 2015, Population Monograph of Nepal, Volume III National Planning Commission Secretariat, Central Bureau of Statistics, Kathmandu, Nepal, 2015

CBS, 2014. National Census of Manufacturing Establishments Nepal2011/12 National Level, Government of Nepal National Planning Commission Secretariat, Central Bureau of Statistics, Kathmandu, Nepal,

MoC 2016. Nepal Trade Integration Strategy 2016 Executive Summary and Action Matrix Government of Nepal Ministry of Commerce Kathmandu

MoF 2018. Economic Survey 2017/018, Nepal Government, Ministry of Finance, Singh Durbar, 2018 (In Nepali)

MoI 2016. Industrial Statistics Fiscal Year (2015/2016), Government of Nepal, Ministry of Industry, Department of Industry, Planning, Monitoring \& Evaluation Division, Tripureswore, Kathmandu, Nepal 
Web sites:

www.moi.gov.np/

http://www.sawtee.org/publications/Research-Brief-3.pdf, A Review of Trade and Industrial Policy in Nepal

https://www.slideshare.net/rajudong/nepal-industrial-policy-2011-reviewRef fncci.org/old/downloads/industrial_policy2067.pdf

Annex-1: Principal Indicators of CME by census year (values are at constant price = 2000/01)

\begin{tabular}{|c|c|c|c|c|c|}
\hline \multirow{2}{*}{ Principal Indicators } & \multicolumn{5}{|c|}{ Census Year } \\
\hline & 1991/92 & 1996/97 & 2001/02 & $2006 / 07$ & 2011/12 \\
\hline No. of establishments & 4271 & 3557 & 3213 & 3446 & 4076 \\
\hline No. of employees & 213653 & 187316 & 181943 & 169891 & 194989 \\
\hline $\begin{array}{lll}\begin{array}{l}\text { Wages/Salaries } \\
\text { benefits ('000 Rs) }\end{array} & \& \quad \text { other } \\
\end{array}$ & 5389434 & 4791997 & 6157356 & 6150560 & 7866931 \\
\hline $\begin{array}{l}\text { Change in stocks at the end of } \\
\text { the year ('000 Rs) }\end{array}$ & 3741606 & 2872270 & 1276509 & 3818083 & 6108463 \\
\hline $\begin{array}{l}\text { Gross addition to fixed assets } \\
\text { ('000 Rs) }\end{array}$ & 3820488 & 3337554 & 2991988 & 4758437 & 2948517 \\
\hline $\begin{array}{l}\text { Gross fixed assets at the end of } \\
\text { the year ('000 Rs) }\end{array}$ & 32298244 & 31282123 & 38903625 & 60319235 & 57290064 \\
\hline Input (value) in ('000 Rs) & 31139922 & 39029406 & 59944856 & 82431910 & 110019819 \\
\hline Output (value) ('000 Rs) & 53109610 & 64861013 & 91364077 & 119238910 & 153482264 \\
\hline Value added in (‘000 Rs) & 21969689 & 25831608 & 31419222 & 36807000 & 43462446 \\
\hline $\begin{array}{l}\text { Average no. of employee per } \\
\text { establishment }\end{array}$ & 50 & 53 & 57 & 49 & 48 \\
\hline Input as percentage of output & 59 & 60 & 66 & 69 & 72 \\
\hline MVA/Employee (‘000 Rs) & 103 & 138 & 173 & 217 & 223 \\
\hline $\begin{array}{l}\text { MVA/Person Engaged in ('000 } \\
\text { Rs) }\end{array}$ & 98 & 131 & 164 & 207 & 213 \\
\hline MVA/Output ratio & 0.41 & 0.40 & 0.34 & 0.31 & 0.28 \\
\hline $\begin{array}{l}\text { MVA per unit of capital in } \\
\text { ('000 Rs) }\end{array}$ & 0.68 & 0.83 & 0.81 & 0.61 & 0.76 \\
\hline
\end{tabular}

